\title{
Die komplekse towerkrag van taal en Tolkien
}

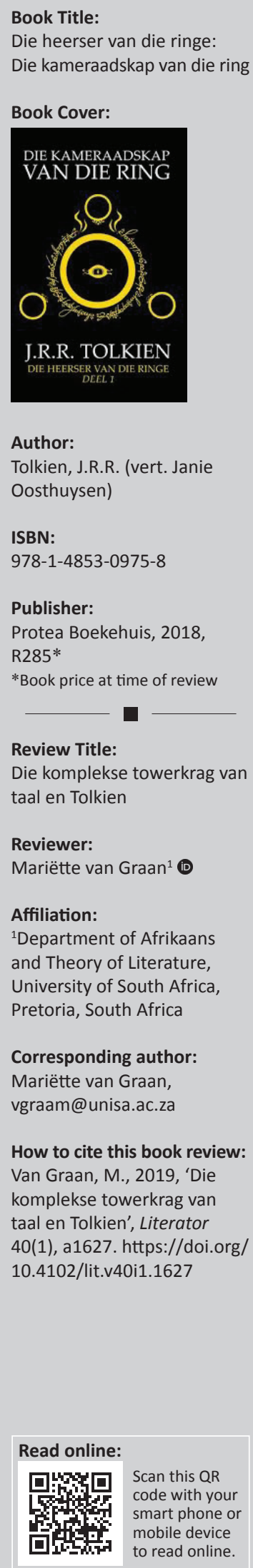

Ná sy avonture in Die Hobbit keer Bilbo Baalens terug na die Graafskap. Hier lewe hy jare lank rustig met sy geheime skat, die ring wat hy by Ghollum afgeneem het. Op sy eenhonderd-en-elfde verjaarsdag neem hy dramaties afskeid van die Graafskap en laat die ring aan sy jong aangenome erfgenaam, Frodo Baalens, agter. Maar die towenaar Ghandalf ontrafel die groot raaisel: Frodo se ring is dié Ring, gesmee deur die bose Sauron om oor al die ander towerringe in Middel-Aarde te heers. As Sauron die Ring terugkry, sal Middel-Aarde aan sy bose heerskappy onderwerp word. Só begin Frodo se avontuur. Hy slaan op die vlug met die Ring en word deur Sauron se bose onderdane gejag. Frodo neem die grootse taak op om die Ring na die Skeure van Verdoemenis in Mordor te neem om dit te vernietig. Hy word op hierdie dodelike missie vergesel deur sy vriende Sam, Mannetjies en Pippin, Ghandalf, die Mense Boromir en Aragorn (Streder), die elf Legolas en die dwerg Gimli - Die Kameraadskap van die Ring.

Die Kameraadskap van die Ring is die eerste boek in Die Heerser van die Ringe trilogie, en die tweede boek waarmee Oosthuysen haar hand aan die vertaling van J.R.R. Tolkien se epiese fantasie waag. In my resensie van haar eerste Tolkien-vertaling, Die Hobbit (2017), is reeds op vertaalprobleme gewys soos die oneweredige hantering van plek- en eiename en die benoeming van spesies, wat ook in hierdie teks kop uitsteek (Van Graan 2017). Ter wille van bondigheid word hierdie kwessies nie hier herhaal nie. Wel opmerklik is die verandering van 'aardgeeste' in Die Hobbit na 'aardmanne' vir goblins in Die Kameraadskap van die Ring. Hierdie vertaling bied nuwe uitdagings, soos die aanspreekvorme en titels Lord en Lady. Lord word vir verskeie manlike karakters na gelang van die situasie as 'heerser', 'heer' of 'vors' vertaal, wat goed werk. Maar dis 'n gesukkel met Lady, waarskynlik vanweë die ou gebruik in heelwat tale (Afrikaans inkluis) om die vroulike aanspreekvorm na gelang van huwelikstatus te bepaal. Die adellike Lady Arwen word nou sommer 'Juffrou' genoem (bl. 270). Sam spreek die magtige Lady Galadriël, mede-heerser van die woude van Lothlóriën, aan as 'Mevrou' (bl. 430), en noem haar enkele bladsye later 'Vorstin' (bl. 436). Ander steurende woordkeuses sluit 'seintuur' (bl. 138) vir belt en girdle in, en Sam se Engelse tussenwerpsel 'of te not' (bl. 429).

Daar is aan paragraafbreuke en sinsbou gekarring - Tolkien se kenmerkende digte, komplekse skryfstyl word skynbaar op plekke vereenvoudig. Hier en daar is ook gevalle waar stukkies belangrike inligting weggelaat of verkeerd oorgedra word. Ghandalf vertel byvoorbeeld in Engels, 'II] decided that I had no time to return to the Shire. Never did I make a greater mistake!', maar in Afrikaans word dit bloot '[Ek het] besluit ek moet na die Graafskap terugkeer. Dit was my grootste fout ooit!' (bl. 302). Boonop het enkele taalfoute by die taalversorger verbygeglip (soos die sin wat met 'n kleinletter begin op bl. 473).

'n Volledige analise van al die kompleksiteite van Tolkien se oorspronklike teks en Oosthuysen se vertaling kan hoegenaamd nie in die bestek van die resensie gedoen word nie, maar diegene wat so 'n studie wil onderneem, word na Tolkien (1975) se eie 'Guide to the names in The Lord of the Rings' verwys (waarby Oosthuysen wel hou), asook Naudé (2019) se tesis (waarin hy self groot dele van die teks vertaal het).

Oosthuysen se vertaling is egter nie noodwendig op akademiese lesers gemik wat dit vergelykend met die bronteks gaan lees en analiseer nie. Dit is veel eerder vir lesers van fantasie en Tolkienaanhangers. Die meeste Afrikaanse lesers wat van fantasie hou, is egter gewoond daaraan om fantasie in Engels te lees. Kultusaanhangers van The Lord of the Rings is waarskynlik nie net met Tolkien se boeke bekend nie, maar ook met Peter Jackson se uiters suksesvolle filmtrilogie. Ikoniese reëls uit die eerste film - soos Ghandalf (vertolk deur sir Ian McKellen) se 'You cannot pass!' en 'Fly, you fools', of Galadriël (vertolk deur Cate Blanchett) se 'In the place of the Dark Lord you will have a queen!', voel lomp en selfs verkeerd wanneer 'n mens in Afrikaans lees 'Jy sal nie verbykom nie!', 'Vlug, julle sotte' (bl. 392) of 'In die plek van die Donker Heer sal jy 'n koningin daar stel' (bl. 435).

Copyright: (C) 2019. The Authors. Licensee: AOSIS. This work is licensed under the Creative Commons Attribution License. 
Tolkien-aanhangers wat sy boeke of die films uit die kop kan opsê, sal waarskynlik wroeg oor hoekom hierdie teks in Afrikaans vertaal is. Gegewe dat fantasie so 'n rariteit in die Afrikaanse letterkunde is, is dit verstaanbaar dat aanhangers van die oorspronklike teks kan voel asof hier nou gekrap word waar dit nie jeuk nie. Dit is ook weliswaar deel van die vertaler se probleem dat daar nog 'n tekort is aan Afrikaanse woordeskat vir hierdie klas magiese wêrelde. Maar hierin lê juis die waarde van Oosthuysen se vertaling. Hierdie boek dra by tot die uitbreiding van so ' $n$ woordeskat, en as dit kommersieel goed vaar, kan dit deure oopmaak vir fantasie in Afrikaans. Dalk sal meer Afrikaanse skrywers die hand daaraan waag. Dalk kan die genre meer lesers wen, wat kan lei tot 'n groter aanvraag na Afrikaanse fantasie, wat weer uitgewers kan aanspoor om meer sulke boeke uit te gee.

Die kritiese leser (veral kultusaanhangers van die oorspronklike teks en akademiese lesers wat vanuit 'n vertalersperspektief lees) kan baie vinnig baie diep in hulle analise van hierdie teks verstrengel raak, en moontlik hierom meer frustrasie as genot uit die boek put. Dit moet egter nie vergeet word watter epiese onderneming dit vir enige vertaler is om Tolkien te vertaal nie. Oosthuysen slaag ten spyte van al die bostaande kwellings baie suksesvol daarin om die towerkrag van Tolkien se wêreld en sy storie aan die leser oor te dra. As jy lus is vir lekker fantasie in Afrikaans, as jy die Engelse boek toeslaan en die films vir 'n wyle kan vergeet, sal jy vinnig meegesleur en ver weggevoer word deur Die Kameraadskap van die Ring.

\section{Literatuurverwysings}

Naudé, E., 2019, " $n$ Afrikaanse vertaling van The Lord of the Rings:'n Ondersoek na die veelsydigheid en heterogeniteit van Afrikaans', M.A. tesis, Fakulteit Lettere en Sosiale Wetenskappe, Universiteit Stellenbosch.

Tolkien, J.R.R. 1975, 'Guide to the names in The Lord of the Rings', in A Tolkien Compass. http://www.tolkien.ro/text/JRR\%20Tolkien $\% 20-\% 20$ Guide $\% 20$ to $\% 20$ the $\% 20$ Names $\% 20$ in $\% 20$ The $\% 20$ Lord $\% 20$ of $\% 20$ the $\% 20$ Rings.pdf.

Van Graan, M., 2017, 'Kan Tolkien se wêreld in Afrikaans verbeel(d) word?', Literator 38(1), a1448. https://doi.org/10.4102.lit.v38i1.1448 